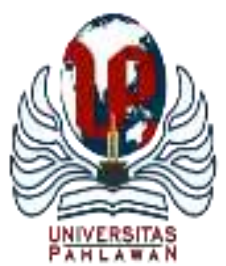

\title{
JURNALBASICEDU
}

\author{
Volume 6 Nomor 1 Tahun 2022 Halaman 1277 - 1284 \\ Research \& Learningin Elementary Education \\ https://jbasic.org/index.php/basicedu
}

\section{Pembinaan Sikap Disiplin Anak Raudhatul Athfal}

\section{Rusydi Ananda ${ }^{1}$, Candra Wijaya ${ }^{2}$, Amrullah Siagian $^{3 凶}$}

Magister PAI Konsentrasi PIAUD, Universitas Islam Negeri Sumatera Utara, Indonesia ${ }^{1,2,3}$

E-mail: rusydiananda@uinsu.ac.id ${ }^{1}$, candrawijaya@uinsu.ac.id ${ }^{2}$, $\underline{\text { amrullahsgn@gmail.com }}^{3}$

\begin{abstract}
Abstrak
Pada penelitian ini bertujuan untuk mengetahui: (1) Pendekatan yang dilakukan oleh para guru dalam membina sikap kedisiplinan anak di RA An-Najamissa'adah Medan Tembung Kota Medan, (2) Alasan dan pertimbangan guru PAUD dalam memilih pendekatan tersebut. Penelitian ini menggunakan jenis penelitian kualitatif dengan pendekatan deskriptif fenomenologis. Peneliti memperoleh data penelitian ini diperoleh dengan menggunakan metode observasi, wawancara dan dokumentasi. Dari temuan dalam penelitian ini dapat disimpulkan bahwa: (1) Bentuk kedisiplinan anak di RA An-Najamissa'adah meliputi: menghargai waktu, budaya mengantri, menjaga kerapian dan kebersihan, sikap bertanggungjawab, sikap kemandirian dan jiwa kepemimpinan (membuat keputusan). (2) Metode yang dilakukan oleh guru RA An-Najamissa'adah dalam membina sikap disiplin anak di RA An-Najamissa'adah meliputi: Metode Uswah (Keteladanan), metode pembiasaan dan metode penugasan, metode pemberian reward, metode pemberian punishment dan pembatasan waktu. (3) Dalam menjaga sikap kedisiplinan anak RA An-Najamissa'adah, guru melakukan pengawasan melalui: proses evaluasi di dalam kelas, dan bekerjasama dengan orang tua / wali murid.
\end{abstract}

Kata Kunci: Sikap Disiplin, Anak Usia Dini

\begin{abstract}
This study aims to determine: (1) the approach taken by the teachers in fostering the discipline of children at RA An-Najamissa'adah Medan Tembung, Medan City, (2) the reasons and considerations of PAUD teachers in choosing this approach. This study uses a qualitative research type with a phenomenological descriptive approach. Researchers obtained research data obtained by using the method of observation, interviews and documentation. From the findings in this study it can be concluded that: (1) The forms of child discipline at RA An-Najamissa'adah include: Respecting time, queuing culture, maintaining neatness and cleanliness, responsible attitude, independent attitude and leadership spirit (making decisions). (2) The methods used by $R A$ An-Najamissa'adah teachers in fostering the discipline of children at RA An-Najamissa'adah include: Uswah (Exemplary) method, habituation method and assignment method, reward method, method of giving punishment and time limitation. (3) In maintaining the discipline of RA An-Najamissa'adah children, the teacher supervises through: the evaluation process in the classroom, and cooperates with parents / guardians of students.
\end{abstract}

Keywords: discipline attitude, early childhood

Copyright (c) 2022 Rusydi Ananda, Candra Wijaya, Amrullah Siagian

$\triangle$ Corresponding author :

Email : amrullahsgn@gmail.com

DOI : https://doi.org/10.31004/basicedu.v6i1.2296

ISSN 2580-3735 (Media Cetak)

ISSN 2580-1147 (Media Online)

Jurnal Basicedu Vol 6 No 1 Tahun 2022

p-ISSN 2580-3735 e-ISSN 2580-1147 
DOI: https://doi.org/10.31004/basicedu.v6i1.2296

\section{PENDAHULUAN}

Masa anak usia dini merupakan waktu yang sangat tepat untuk menanamkan dasar-dasar aqidah, konsep diri, etika, estetika, seni dan lain-lain, karena pada masa ini otak anak berkembang sebanyak $90 \%$. Tujuan penanaman konsep-konsep ini diantaranya untuk melatih Ego atau keakuan pada anak supaya tahu dan mampu untuk menjaga kepemilikan dan harga dirinya serta belajar untuk berbagi dengan sesama (Nurfuadi, 2011). Dalam hal ini, perlu dilakukan pemberian rangsangan pendidikan untuk membantu pertumbuhan dan perkembangan fisik dan psikis, agar anak memiliki kepribadian dan karakter yang luhur dalam proses jenjang kehidupannya, yang selanjutnya disebut sebagai proses pendidikan karakter.

Pendidikan karakter adalah hal penting yang monumental untuk diberikan kepada anak usia dini. Sebab karakter merupakan mahkota yang paling tinggi dalam status kemanusiaan seseorang selama hidup di dunia. Menurut (M. Fadilah, 2013), pendidikan karakter meliputi delapan belas macam nilai karakter yang dapat diberikan kepada anak melalui berbagai kegiatan baik yang bersifat universal maupun kelompok. Nilai karatkter tersebut meliputi religius, jujur, toleransi, disiplin, kerja keras, kreatif, mandiri, demokratis, rasa ingin tahu, semangat kebersamaan, cinta tanah air, menghargai potensi (respect), bersahabat, cinta damai, gemar membaca, peduli lingkungan, peduli sosial, dan tanggung jawab (responsibel).

Disiplin pada anak merupakan upaya yang dapat ditanamkan melalui pembiasaan yang dilakukan secara terarah dan terukur, anak diarahkan berbuat baik dan selalu melakukan perbuatan yang rutin sebagai perilaku yang terukur, seperti halnya dalam menjalankan ibadah dan ketaatan dalam ajaran agama, anak dapat melakukan dengan baik dan secara terus menerus. Disiplin yang baik sebagaimana Lukman mendidik anaknya disiplin dengan nilai kejujuran, ketaatan dan sebagainya (Nurazizah, 2017).

Penelitian mengenai pembinaan sikap disiplin anak telah banyak dilakukan sebelumnya, seperti penelitian menyimpulkan pola asuh lingkungan keluarga khususnya orang tua sangat menentukan karakter disiplin anak, sehingga perlu menganalisis dan mengetahui bagaimana hubungan pola pengasuhan keluarga dalam pembentukan karakter disiplin anak (Prasetyo, 2021). Sedangkan menurut penelitian lain (Aulina, 2013), kedisiplinan anak-anak perlu ditanamkan tanpa harus dipaksakan oleh orang tua, guru, maupun orang dewasa. Dengan kedisiplinan itu anak dapat mengetahui manfaat dari kedisiplinan itu untuk kehidupan yang lebih baik lagi.

Dalam membina sikap kedisiplinan kepada anak usia dini, tentu bukanlah hal yang mudah. Mengingat, anak usia dini identik dengan dunia bermain. Melihat budaya antri yang dilakukan oleh para anak usia dini yang berumur antara 3-5 tahun di RA An-Najamissa'adah, Peneliti memahami bahwa ada strategi dan taktik yang secara terstruktur dilakukan oleh guru, orang tua maupun lembaga PAUD dalam mengkombinasikan dunia bermain dan dunia belajar menjadi satu perpaduan utuh yang ditransformasikan kepada anak usia dini. Berawal dari asumsi inilah, Peneliti tertarik untuk mendalami fenomena ini secara teoritis dan praktis dengan melakukan sebuah penelitian kualitatif deskriptif yang berjudul "Pembinaan Sikap Disiplin Anak di RA Annajamissa' adah Medan Tembung Kota Medan".

\section{METODE PENELITIAN}

Penelitian ini menggunakan pendekatan penelitian kualitatif. Penelitian kualitatif merupakan sebuah penyelidikan untuk memahami masalah sosial berdasarkan pada penciptaan gambar holistik yang dibentuk dengan kata-kata, melaporkan berbagai pandangan informan secara terperinci dan disusun dalam latar ilmiah. Adapun yang dimaksud penelitian deskriptif kualitatif adalah cara pandang penelitian induktif yang berfokus untuk mengeksplorasi dan memahami makna individual, dan menterjemahkan suatu persoalan (Creswell, 2010). 

Siagian

DOI: https://doi.org/10.31004/basicedu.v6i1.2296

Subjek penelitian ini menggunakan dua subjek yaitu subjek primer dan subjek sekunder. Subjek primer yaitu 5 guru dan 60 anak di RA Annajamissa'adah di jalan pukat III No. 5 medan Tembung Kota Medan. Subjek sekunder yaitu kepala sekolah dan wali murid RA Annajamissa'adah di jalan pukat III No. 5 medan Tembung Kota Medan. Objek pada penelitian ini adalah masalah yang diteliti berupa segala aktivitas, strategi dan metode yang dilakukan oleh para guru dalam proses pembinaan sikap disiplin anak usia dini di RA Annajamissa'adah di jalan pukat III No. 50 Medan Tembung Kota Medan. Teknik pengumpulan data yang digunakan dalam penelitian ini adalah wawancara kepada 6 guru, kepala sekolah dan 5 orang tua murid, dan melakukan pengamatan (observasi) terhadap anak di RA Annajamissa'adah di jalan pukat III No. 50, Medan Tembung Kota Medan Tahun pelajaran 2020/2021.

\section{HASIL DAN PEMBAHASAN}

Berdasarkan hasil dari pengamatan dan wawancara yang dilakukan peneliti terhadap proses pembinaan sikap disiplin anak usia dini di RA An-Najamissa'dah Medan Tembung Kota Medan, ada beberapa rangakaian proses pelaksanaan yang didesain oleh para guru selama para murid berada di lingkungan madrasah. Baik ketika para murid tiba di madrasah hingga proses pembelajaran berakhir. Rangkaian persiapan yang dilakukan terhadap para anak usia dini sebelum memasuki kelas adalah salah satu hal yang paling penting untuk diperhatikan oleh para guru PAUD. Mengingat pada bagian ini, akan sangat menetukan persiapan fisik dan psikis anak dalam mengikuti pembelajaran di dalam kelas. Tanpa terkecuali, pembinaan sikap disiplin bagi para anak usia dini. Dengan demikian, bagian ini menjadi kunci dan berperan penting dalam menentukan proses pembelajaran yang akan berlangsung bagi anak usia dini.

\section{Pendidikan Karakter Anak Usia Dini}

Karakter atau akhlak dapat diukur secara tepat apabila kedua seginyadiperhatikan. Pendidikan Islam bertujuan untuk menanamkan nilai Karakter atau akhlak yang nantinya bisa terwujud dalam bentuk perilaku danmembentuk satu kepribadian. Nilai dalam Pendidikan Islam berkisar antara dua demensi yakni nilai-nilai Ilahiyah dan nilai-nilai Insaniyah (Andayani, 2011). Nilai-nilai Ilahiyah dapat dikembangkan dengan menghayati keagungan dan kebesaran Tuhan lewat perhatian kepada alam semesta beserta segala isinya, dan kepada lingkungan sekitar.

Karakter seseorang berkembang berdasarkan potensi yang dibawanya sejak lahir atau yang dikenal sebagai karakter dasar yang bersifat biologis. Menurut Ki Hajar Dewantara, aktualisasi karakter dalam bentuk perilaku sebagai hasil perpaduan anatar karakter biologis dan hasil hubungan atau interaksi dengan lingkungannya. Adapun karakter dapat dibentuk melalui pendidikan, karena pendidikan merupakan alat yang paling efektif untuk menyadarkan individu dalam jati diri kemanusiaannya (Zubaedi, 2011). Pendidikan karakter merupakan pendidikan yang sangat penting yang harus mulai ditanamkan pada diri anak sejak usia dini. Karena usia dini merupakan masa keemasan anak (golden age) dimana anak akan belajar mengimitasi segala ucapan yang ia dengar dan aktivitas yang terus menerus disaksikannya secara berulang dalam kehidupan.

Pendidikan Akhlak (karakter) dalam pendidikan Islam, memiliki banyak demensi nilai yang dapat dijadikan pedoman akan tetapi selain nilai-nilai dasaryang penulis telah jabarkan di atas, penulis disini juga memaparkan nilai-nilai pendidikan akhlak dalam pribadi Rasulullah SAW yang menjadi sosok uswatuh hasanah yang terangkum dalam Karakter SAFT. Karakter SAFT adalah singkatan dari empat karakter yaitu : Shidiq, Amanah, Fathonah, dan Tabligh. Muhammad Fadilah, Pendidikan karakter merupakan suatu sistem penanaman nilai- nilai karakter pada peserta didik yang meliputi komponen: kesadaran, pemahaman, kepedulian, dan komitmen yang tinggi untuk melaksanakan nilai-nilai tersebut (M. Fadilah, 2013). 
Karakter disiplin anak dibentuk dengan pengaturan kondisi lingkungan keluarga dan peran orang tua dalam hal disiplin anak sangat penting, orang tua dalam menunjang pendidikan anak sebaik mungkin adalah dengan mengupayakan meluangkan waktu yang cukup pada anak dan melakukan komunikasi yang baik (Chucniatun, 2015). Peran orang tua lainnya adalah Kerjasama orang tua dan pihak sekolah dalam membentuk karakter yang baik pada anak (Riati, 2016).

Implementasi Pendidikan karakter dalam Islam tersimpul dalam karakter pribadi Rasulullah saw. Dalam pribadi Rasul, bersemai nilai-nilai karakter yang mulia dan agung. Allah berfirman dalam Al-Quran surah alAhzab ayat 21:

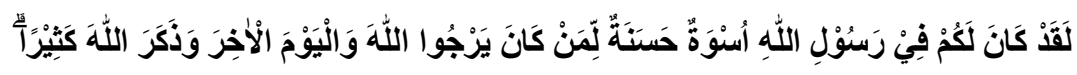

Artinya: "Sesungguhnya telah ada pada (diri) Rasulullah itu suri teladan yang baik bagimu (yaitu) bagi orang yang mengharap (rahmat) Allah dan (kedatangan) hari kiamat dan Dia banyak menyebut Allah".

Sebagai usaha yang identik dengan ajaran agama, perlu dimengerti bahwa Islam diturunkan oleh Allah SWT sebagai agama dan tuntunan hidup bagi umat manusia yang ada di dunia. Islam sebagai rangkaian nilai diharapkan mampu untuk membawa kedamaian dan kesejahteraan bagi seluruh umat manusia. Islam tidak hanya diperuntukkan bagi segelintir orang dan kelompok, melainkan kepada seluruh alam semesta, serta pengejawantahan nilai-nilai keislaman seharusnya dirasakan oleh seluruh manusia, termasuk kepada manusia yang tidak memeluk Islam.

\section{Kedisiplinan Anak RA An-Najamissa'adah}

Menurut (Lickona, 2013), disiplin adalah moralitas kelas sebagai masyarakat kecil. Artinya nilai-nilai kedisiplinan bagi anak terutama di PAUD bukan saja disiplinin waktu, lalu lintas, disiplin belajar, disiplin belajar sesuai waktu akan tetapi di tentukan dengan berbagai aspek dan tata krama kehidupan (Setiawan, 2017). Menurut (M. Fadilah, 2013), mengartikan disiplin lebih spesifik yaitu disiplin mencakup pengajaran bimbingan atau dorongan yang dilakukan oleh orang dewasa tujuannya menolong anak belajar untuk hidup sebagai mahluk sosial dan untuk mencapai pertumbuhan serta perkembangan mereka yang optimal. Menurut Hurlock yang dimaksud disiplin adalah prilaku seseorang yang belajar diri atau secara sukarela mengikuti seorang pemimpin, orang tua dan guru merupakan pemimpin, sedangkan anak merupkan murid yang belajar dari orang dewasa tentang hidup yang menuju kearah kehidupan yang berguna dan bahagia dimasa mendatang. Menurut Gunawan disiplin sekolah artinya setiap anak harus mengikuti aturan dan tata tertib sekolah seperti cara berpakaian yang rapih dan ketepatan waktu.

Menurut Suryadi disiplin merupakan suatu sistem pengendalian yang diterapkan oleh pengendalian yang di terapkan oleh pendidik terhadap anak didik agar mereka dapat berfungsi di masyarakat, seperti yang dikatakan oleh Hadiyanto disiplin adalah suatu keadaan dimana sikap dan penampilan, seorang peserta didik sesuai dengan tatanan nilai, norma dan ketentuan-ketentuan yang berlaku disekolah dimana peserta didik berada. Disiplin merupakan suatu ketaatan dan kepatuhan terhadap sesuatu yang telah disepakati, sehingga disiplin menjadi penting diajarkan pada anak usia dini supaya dapat belajar berperilaku dengan cara yang diterima oleh masyarakat dan oleh anggota kelompok sosial mereka. Tujuan disiplin bagi anak usia dini terbagi atas tujuan jangka pendek dan jangka panjang, adapun tujuan jangka pendek adalah membuat anak usia dini terlatih dan terkontrol, dengan meng ajarkan bentuk perilaku yang pantas dan tidak pantas sedangkan tujuan jangka panjang adalah membentuk perkembangan pengendalian diri (Suryono, 2014).

Jadi, secara sederhana kedisiplinan anak usia dini pada dasarnya adalah sikap taat dan patuh terhadap aturan yang berlaku,baik di rumah, sekolah, maupun masyarakat yang dilakukan oleh anak usia 0-6 tahun. Dengan demikian Sehingga dikatakan bahwa disiplin adalah proses bimbingan yang bertujuan menanamkan pola prilaku tertentu, kebiasaan-kebiasaan tertentu atau membentuk manusia dengan ciri- ciri tertentu, yang meningkatkan kualitas mental dan moral (Wiyani, 2013). 
Adapun rangkaian proses yang dilakukan oleh para guru dalam memberlangsungkan pembinaan sikap disiplin bagi anak usia dini di RA An-Najamissa'adah dapat diuraikan dengan beberapa bagian meliputi: Pembiasaan hadir tepat waktu, pembiasaan budaya mengantri, penanaman sikap kerapian, dan pembinaan sikap mandiri anak. Mengenai hal ini, dapat dilihat dari hasil observasi, wawancara dan dokumentasi penelitian yang dirangkum dalam penjelasan hasil temuan sebagai berikut:

\section{a. Menghargai waktu}

Sebagaimana observasi yang peneliti lakukan, anak RA An-Najamissa'adah memiliki keterampilan menghargai waktu yang baik. Hal ini dapat dilihat ketika anak usia dini hadir ke sekolah dengan tepat waktu sebelum proses pembelajaran dimulai. Selain itu, anak juga langsung menyimpan peralatan bermainnya setelah waktu bermain berakhir. Ditambah lagi dengan kedisiplinan anak saat mengumpulkan tugas yang guru berikan baik di dalam kelas maupun pekerjaan rumah. Para anak secara tertib memberikan hasil kerjanya ke meja guru seseuai dengan rentang waktu yang diberikan.

\section{b. Budaya antri}

Dengan menerapkan teknik yang tepat dan sesuai dengan perkembangan anak memungkinkan budaya antri dapat diajarkan secara baik kepada anak. Hal ini dapat dilihat dari kebiasaan yang dilakukan oleh anak di RA An-Najamissa'adah dimana anak sudah terbiasa dalam menyusun barisan sebelum memasuki kelas, anak secara berurutan masuk kelas dan keluar kelas, anak bergiliran ketika ingin bertanya, anak tidak berdesak-desakan ketika ingin maju kedepan kelas mengumpulkan tugas yang guru berikan, anak secara bergiliran dalam menggunakan permainan, dan anak juga tidak terburu-buru bersalaman dengan guru ketika berpamitan ingin pulang.

\section{c. Menjaga kerapian dan kebersihan}

Hal ini dapat dilihat dari kebiasaan anak RA An-Najamissadah dalam menjaga kerapian dirinya dan kebersihan kelas. Dimana setiap anak akan berusaha merapikan pakaiannya saat berada di dalam dan di luar kelas. Tidak jarang, anak meminta bantuan kepada guru ketika dia mengalami kesulitan dalam merapikan pakaiannya. Begitu juga disaat pembelajaran akan dimulai, anak akan merapik an meja belajar dan membuang sampah jika terdapat sampah di sekitar meja belajarnya. Selain itu, anak juga akan mencuci tangan mereka setiap kali selesai bermain. Ini merupakan sesuatu keterampilan yang harus diperhatikan dalam perkembangan sikap disiplin bagi anak usia dini, mengingat betapa pentingnya membiasakan diri untuk hidup dengan lingkungan yang indah, bersih dan sehat.

\section{d. Sikap kemandirian}

Sikap disiplin bukanlah bawaan lahir yang sudah dimiliki oleh seseorang, melainkan menjadi salah satu sikap yang perlu ditanamkan dan diajarkan pada anak sejak usia dini. Untuk menjadi pribadi yang disiplin, mereka membutuhkan persiapan. Untuk itu, Mama bisa mempersiapkan diri mereka sebaik mungkin agar anak memiliki sikap disiplin dan belajar memerhatikan segala sesuatu secara lebih detail.

\section{e. Sikap bertanggung jawab}

Berdasarkan hasil observasi yang peneliti lakukan terkait dengan sikap kedisiplinan dalam diri anak di RA An-Najamissa'adah, peneliti menemukan beberapa rangkaian kegiatan dimana anak terlihat cukup mandiri dalam menyusun sepatu, menyimpan tas, menyimpan permainan dan peralatan belajar. Ini juga merupakan sebuah kemajuan besar dalam diri anak mengingat keterampilan ini adalah wujud kesadaran dimana anak telah memahami dan mengerti akan kewajiban dan tanggung jawab dirinya sebagai seorang anak.

\section{f. Jiwa kepemimpinan}

Hal ini dapat dilihat dari hasil pengamatan peneliti, dimana anak RA An-Najamissa'adah diajarkan untuk memilih ketua kelompok bermainnya. Selain menumbuhkan sikap berani dalam diri anak, anak juga terlatih untuk membuat keputusan yang baik di dalam kelompok bermainnya. Demikian pula disaat kondisi kelas atau meja belajar anak dalam keadaan yang tidak bersih. Anak terlihat inisiatif untuk segera 
1282 Pembinaan Sikap Disiplin Anak Raudhatul Athfal - Rusydi Ananda, Candra Wijaya, Amrullah Siagian

DOI: https://doi.org/10.31004/basicedu.v6i1.2296

membuang sampah pada tempatnya.

Dalam menerapkan disiplin orang tua atau guru hendaknya menggunakan metode atau cara yang dapat menambah motivasi anak untuk berprilaku baik. Jadi peraturan atau disiplin itu dilakukan oleh semua orang (Wantah, 2005). Adapun strategi dan metode yang digunakan guru untuk pembinaan sikap disiplin anak RA An-Najamissa'adah, yaitu:

\section{a. Metode pembiasaan}

Dalam penggunaan sikap, metode pembiasaan sangat efektif digunakan karena melatih kebiasaankebiasan yang baik bepada anak sejak dini, itu sudah dapat diartikan sebagai usaha pembiasaan, bila murid masuk kelas tidak mengucap salam, guru mengingatkan agar bila masuk ruangan hendaknya mengucapkan salam. Ini uuga satu cara membiasakan anak sejak dini. Dalam pembinaan disiplin, metode pembiasaan sebenarnya cukup efektif. Sejalan dengan pendapat mengemukakan tujuan metode pembiasaan adalah agar anak memperoleh sikap-sikap dan kebiasaankebiasaan baru yang lebih tepat dan positif dalam arti selaras dengan kebutuhan ruang dan waktu (kontekstual) (Nurul Ihsani, Nina Kurniah, 2018).

Demikian penjelasan yang diperoleh oleh peneliti berdasarkan hasil observasi dan wawancara di RA AnNajamissa'adah tentang pembiasaan membariskan para murid baik sebelum memasuki kelas maupun sesudah proses pembelajaran kelas berakhir. Dan pembiasaan seperti ini secara rutin dipraktikkan di RA An-Najamissa'adah Medan Tembung Kota Medan sebagai salah satu upaya yang nyata dalam membangun karakter kedisiplinan dalam diri anak terutama dalam mempraktikkan budaya mengantri dalam kehidupan masyarakat kelak.

Dengan demikian, pembiasaan bersalaman secara bergantian yang dilakukan oleh para guru RA AnNajamissa'adah di setiap pagi dan ketika akhir pembelajaran merupakan salah satu upaya massif dan berkelanjutan dalam upaya menanamkan nilai-nilai moral dan sosial terkhusus pembiasaan sikap mengantri dalam diri anak usia dini. Meskipun demikian, peran orang tua/wali juga sangat diperlukan dalam menindaklanjuti rangkaian pembelajaran yang telah disampaikan oleh para guru. Sebab tidak bisa dipungkiri, keberhasilan guru terutama dalam menanamkan budaya mengantri dalam diri anak saat berada di lingkungan madrasah, haruslah didukung oleh kesadaran para orang tua/wali saat anak berada di lingkungan keluarga/rumah.

\section{b. Metode keteladanan}

Metode keteladanan adalah metode influtif yang paling meyakinkan keberhasilannya dalam mempersiapkan dan membentuk moral dan sosial anak. Sebab, pendidikan adalah contoh terbaik dalam pandangan anak yang akan ditiru dalam tindakan-tindakan dan sopan santunya terpatri dalam jiwa. Metode ini sesuai di gunakan untuk menanamkan nilai-nilai moral dan sosial anak, hal ini juga merupakan implikasi ayat yang memerintahkan untuk meneladani Nabi Muhammad SAW (Sanusi, 2006).

Dari informasi yang penelti peroleh bahwa salah satu cara untuk membina sikap kedisiplinan anak usia dini di RA An-Najamissa'adah adalah para guru hadir di madrasah 15 menit lebih awal sebelum jam belajar untuk memberikan keteladanan tentang menghargai waktu kepada para murid dengan bantuan dan kerjasama dari para orang tua/wali murid.

Kemudian, kebiasaan anak untuk membuang sampah pada tempatnya merupakan sebuah proses panjang dimana para guru telah mencontohkannya terlebih dahulu dengan memastikan lingkungan madarasah dalam keadaan bersih sebelum para anak memasuki ruangan kelas. Ruangan kelas yang bersih ini, tentu menjadi motivasi tersendiri bagi anak untuk membuang sampah pada tempatnya. Sekaligus membantu guru untuk melakukan transfer of value ke dalam diri anak untuk senantiasa menjaga kebersihan lingkungan. 
1283 Pembinaan Sikap Disiplin Anak Raudhatul Athfal - Rusydi Ananda, Candra Wijaya, Amrullah Siagian

DOI: https://doi.org/10.31004/basicedu.v6i1.2296

\section{c. Metode Penugasan}

Dari penjelasan di atas, kita bisa menyaksikan bahwa RA An-Najamissa'adah menaruh perhatian khusus pada kerapian dan kebersihan kelas. Hal ini dapat dilihat dari perhatian yang guru berikan dengan selalu mengingatkan anak agar membersihkan meja belajar dan rutin mencuci tangan. Semua ini diberlangsungkan dalam upaya mendisiplinkan anak dalam menjaga kebersihan lingkungaan sekitarnya. Ditambah lagi dengan sarana dan prasarana yang mendukung para guru terbantu dalam proses membelajarkan anak tentang kerapian dan kebersihan kelas.

Dari penjelasan di atas, dapat dipahami bahwa melalui pembiasaan menyimpan peralatan bermain yang diterapkan kepada anak di RA An-Najamissa'adah merupakan sebuah metode pembelajaran yang bertujuan agar anak bisa mengerti bahwa peralatan bermain bukan hanya untuk sekedar dimainkan oleh anak, melainkan ada kewajiban di dalam dirinya untuk menjaganya agar tidak rusak dan hilang. Secara tidak langsung, metode ini adalah salah satu upaya guru menumbuhkan rasa tanggung jawab dalam diri anak di RA An-Najamissa'adah.

Salah satu upaya menumbuhkan sikap tanggung jawab dalam diri anak adalah dengan memberikan tugas di dalam kelas, sebab selesai atau tidaknya tugas tersebut menjunjukkan tingkat pertanggungjawaban anak terhadap kewajibannya.

Dengan adanya metode penugasan memberikan suatu kegiatan yang menyenangkan pada anak hingga berdampak pada tumbuhnya aktivitas belajar yang lebih tinggi (Megawati, 2021).

\section{d. Metode Reward}

Melalui pemberian reward tentu saja anak akan merasa gembira. Selain itu ia juga akan merasa dihargai, belajar yang ia lakukan dengan tekun dan penuh perjuangan mendapatkan sebuah penghargaan. Memang dengan ia mendapatkan sebuah prestasipun anak pasti sudah senang akan tetapi dengan reward ini menjadi sebuah bukti nyata dan sebuah apresiasi atas apa yang telah anak capai. Berkat penghargaan inilah semangat anak untuk terus belajar akan semakin meningkat terkhusus dalam hal kedisiplinan (Mufidah, 2012).

\section{e. Metode Punishment}

Dengan demikian, berdasarkan hasil penelitian yang peneliti peroleh dapat disimpulkan bahwa salah satu upaya yang dilakukan oleh para guru RA An-Najamissa'adah dalam membina kedisiplinan anak agar hadir tepat waktu di madrasah adalah memberikan punishment positif terhadap anak dengan pendampingan dari guru dalam menyelesaikan punishment yang sedang diterimanya. Hal ini diperlukan agar anak tidak kehilangan rasa percaya diri saat berada di dalam kelas sekaligus sebagai upaya membangun mental keberanian dalam diri anak saat berada di depan kelas.

Sesuai dengan penjelasan di atas, menurut punishment merupakan suatu perbuatan yang dilakukan dengan sadar maupun sengaja sehingga menyebabkan kesedihan oleh orang lain, dengan hal ini seorang pendidik di percaya untuk membimbing dan melindungi dengan hukuman tersebut diberikan agar anakanak merasakan kesedihan tersebut (Sadulloh, 2010).

\section{KESIMPULAN}

Berdasarkan hasil penelitian dan pembahasan pada bab sebelumnya, penelitian ini memberikan kesimpulan sebagai berikut :1) Dalam proses pembinaan sikap kedisiplinan bagi anak usia dini di RA AnNajamissa'adah, Kepala Madrasah menaruh perhatian khusus kepada para guru untuk benar-benar mampu menjadi orang tua yang baik sekaligus guru yang diidolakan oleh setiap anak. 2) Guru RA An-Najamissa'adah selalu menggunakan metode dan strategi yang sangat sederhana namun dilakukan secara terstruktur dan kerjasama yang baik diantara para guru. 3) Kemampuan guru dalam memahami setiap perkembangan setiap 
1284 Pembinaan Sikap Disiplin Anak Raudhatul Athfal - Rusydi Ananda, Candra Wijaya, Amrullah Siagian

DOI: https://doi.org/10.31004/basicedu.v6i1.2296

anak usia dini, menjadi faktor penting bagi guru dalam memilih pendekatan yang efektif dan efesien dalam membelajarkan anak.

\section{DAFTAR PUSTAKA}

Andayani, A. M. \& D. (2011). Pendidikan Karakter. Remaja Rosdakarya.

Aulina, C. N. (2013). Penanaman Disiplin Pada Anak Usia Dini. Jurnal Pedagogia, 2(1).

Chucniatun, Q. P. A. \&. (2015). Peran Orang Tua Dalam Pendidikan Anak Usia Dini. Jurnal Indegenous, 13(2).

Creswell, W. J. (2010). Research Design Pendekatan Kualitatif, Kuantitatif Dan Mixed. Pustaka Pelajar.

Lickona, T. (2013). Pendidikan Karakter Panduan Lengkap Mendidik Siswa Menjadi Pintar Dan Baik. Nusa Media.

M. Fadilah, K. (2013). Pendidikan Karakter Anak Usia Dini. Ar-Ruzz Media.

Megawati, N. K. S. (2021). Penerapan Metode Penugasan Berbantuan Media Fun Thinkers Book Untuk Meningkatkan Perkembangan Kognitif Anak Di Kelompok A. Prosiding Seminar Nasional Penelitian Dan Pengabdian.

Mufidah, U. (2012). Efektivitas Pemberian Reward Melalui Metode Ekonomi Untuk Meningkatkan Kedisiplinan Anak Usia Dini. Journal Of Early Childhood Education, 1(1).

Nurazizah, E. F. \& M. G. (2017). Pendidikan Karakter Untuk Anak Usia Dini Menurut Q.S Lukman: 13-19. Pedagogi: Jurnal Aud Dan Paud, 3(3).

Nurfuadi, M. R. \&. (2011). Kepribadian Guru. Stain Press.

Nurul Ihsani, Nina Kurniah, A. S. (2018). Hubungan Metode Pembiasaan Dalam Pembelajaran Dengan Disiplin Anak Usia Dini. Jurnal Ilmiah Potensia, 3(1).

Prasetyo, F. U. Dan I. (2021). Pengasuhan Keluarga Terhadap Perkembangan Karakter Disiplin Anak Usia Dini. Jurnal Obsesi2, 5(2).

Riati, I. K. (2016). Pengaruh Pola Asuh Orang Tua Terhadap Karakter Anak Usia Dini. Jurnal Infantia, 4(2).

Sadulloh, U. (2010). Pedagogik (Ilmu Mendidik). Alfabeta.

Sanusi, A. (2006). Jalan Kebahagiaan. Gama Insani.

Setiawan, C. R. (2017). Metode Penelitian Kualitatif. Grasindo.

Suryono, E. M. Dan Y. (2014). Peran Orang Tua Dan Pendidik Dalam Menerapkan Perilaku Disiplin Terhadap Anak Usia Dini. Jurnal Pendidikan Dan Pemberdayaan Masyarakat, 1(2).

Wantah, M. J. (2005). Mengembangan Disiplin Dan Pembentukan Moral Pada Anak Usia Dini. Depdiknas.

Wiyani, N. A. (2013). Pendidikan Agama Islam Berbasis Pendidikan Karakter. Alfabeta.

Zubaedi. (2011). Desain Pendidikan Karakter. Kencana. 